\title{
Erosive potential of different types of grape juices
}

\author{
Ginna Kércia Matos Gonçalves ${ }^{(a)}$ \\ Camila de Almeida Brandão \\ Guglielmi $^{(b)}$ \\ Fernanda Nahás Pires Corrêa ${ }^{(c)}$ \\ Daniela Prócida Raggio(b) \\ Maria Salete Nahás Pires Côrrea ${ }^{(b)}$
}

(a) Pediatric Dentistry Department, Universidade Cruzeiro do Sul, São Paulo, SP, Brazil.

(b) Pediatric Dentistry and Orthodontics Department, School of Dentistry, University of São Paulo, São Paulo, SP, Brazil.

(c) Pediatric Dentistry, School of Dentistry, Sao Leopoldo Mandic Dental Research Center, Campinas, SP, Brazil.
Declaration of Interests: The authors certify that they have no commercial or associative interest that represents a conflict of interest in connection with the manuscript.

Corresponding Author: Camila Almeida Brandão Guglielmi E-mail: camigugli@usp.br

Submitted: Feb 28, 2012

Accepted for publication: May 10, 2012 Last revision: May 22, 2012
Abstract: The purpose of the present study was to evaluate the erosive potential of different types (concentrated and powdered) and commercial brands of industrialised grape juices. The $\mathrm{pH}$ of all five fruit drinks was measured at two time points: immediately after preparation and 24 hours later. Sixty specimens of bovine enamel were randomly allocated and immersed in different types of grape juice $(n=10)$ for 10 minutes four times a day for fifteen days. The enamel alteration was analysed using surface Knoop microhardness $(\mathrm{KHN})$ and surface roughness $\left(\mathrm{R}_{\mathrm{a}}\right)$ tests at baseline and on the $5^{\text {th }}, 10^{\text {th }}$ and $15^{\text {th }}$ days of the experiment. Two way ANOVA, Tukey's post hoc and Pearson's correlation tests were used for statistical analysis $(\alpha=5 \%)$. The grape juices presented $\mathrm{pH}$ values ranging from 2.9 to 3.5. All of the tested juices promoted significant enamel mineral loss $(\mathrm{p}<0.05)$ on the first evaluation $\left(5^{\text {th }}\right.$ day of immersion) and produced a significant increase in the mean roughness from the $10^{\text {th }}$ day on when compared to the control group $(\mathrm{p}<0.05)$. By the $15^{\text {th }}$ day, all of the beverages had produced surface roughnesses that were significantly higher than that of the control group. The results suggest that all grape juices, regardless of their commercial presentation, present erosive potential.

Descriptors: Dental Enamel; Tooth Erosion; Hydrogen-Ion Concentration.

\section{Introduction}

Dental erosion can be clinically defined as the consequence of irreversible mineral loss from tooth surfaces due to an acidic dissolution process not involving bacteria from oral biofilms. Along with attrition and abrasion, dental erosion is considered an important factor in tooth wear and may be caused by a series of extrinsic factors, such as dietary habits, and intrinsic factors, such as gastroesophageal reflux. ${ }^{1}$ Prevalence data for tooth erosion has attracted the attention of the dental community, and the increased consumption of soft drinks by children and young adults is of particular concern. Frequent intake of acidic beverages commonly leads to widespread dental erosion, but this condition can be prevented if the patient is advised by dental professionals.

Tooth erosion is increasingly recognised as a common occurrence in paediatric dentistry, and high prevalence numbers ranging from $30 \%$ to $68 \% \%^{2,3}$ have been documented. The main related complications are tooth sensitivity and the loss of occlusal vertical dimension; however, compro- 
mised aesthetics may also be a concern. Primary teeth are thought to be more susceptible to erosion than permanent teeth because primary teeth have a thinner enamel and a lower mineral content; ${ }^{4}$ however, this information is controversial. ${ }^{5}$ The importance of identifying erosion should be emphasised for dental professionals because prevention is the only effective measure against this occurence. Severe lesions near the pulp chamber can also occur, especially in deciduous teeth; ${ }^{5}$ however, care must also be taken with regard to permanent dentition, which begins in childhood. If erosive lesions are detected in deciduous dentition and no education about dietary habits is provided, it is very possible that the permanent teeth will be compromised in the future.

Lifestyles are constantly changing, and dietary factors, namely, high consumption of acidic beverages, currently represent the most important external risk factor for erosion in children and adults. ${ }^{1,6}$ Lussi et al. ${ }^{7}$ found that orange juice produced marked loss of hardness in primary and permanent enamel, and fruit juices have been found to be much more destructive to the teeth than whole fruit is. ${ }^{8}$

Al-Majed et al. ${ }^{9}$ reported that the number of permanent incisors with erosion in children was associated with the frequency of night-time beverage intakes and the length of time the beverage is held in the mouth before swallowing, and the frequency of fruit and carbonated drink intakes was found to be related to severe enamel erosion in Irish children. ${ }^{6}$ Therefore, the present study aimed to compare the erosive potential of different types of industrialised grape juice using an in vitro model, as fruit juices are one of the beverages that children consume most frequently. ${ }^{10}$ Although some studies tested the erosive capacity of apple juice in primary and permanent dentition, ${ }^{11}$ grape juice has rarely been studied, especially with respect to different presentations of grape juice.

\section{Methodology}

Sixty enamel blocks $(4 \times 7 \mathrm{~mm})$ were obtained from the middle third of bovine incisor teeth that had previously been stored in tap water at room temperature for 30 days. The enamel surfaces were examined at $2 \times$ magnification with a stereoscopic microscope (Nikon, Tokyo, Japan) to ensure that the selected sites did not have caries, cracks or intrinsic staining, and a low-speed saw (Labcut 1010 - Extec Corp., London, England) was used to obtain the blocks. Each block was then embedded in acrylic resin.

\section{Sample preparation}

The sample surfaces were planed with a watercooled automatic grinding/polishing machine with $600,1,000,1,200$ and 4,000 grit sandpaper discs under running water for $30 \mathrm{~s}(\# 600)$ and $60 \mathrm{~s}$ and polished with diamond paste ( 3 and $1 \mu \mathrm{m}$; Ecomet 3 , Bueller, USA). Before and after the polishing procedure, the samples were cleaned in an ultrasonic cube. Afterward, the samples were stored under conditions of $100 \%$ humidity.

The specimens were then randomly assigned into 6 groups, according to the type of grape juice tested (Table 1). The juices were prepared according to the manufacturer's instructions.

The $\mathrm{pH}$ of all beverages was measured at two time points:

- immediately after the packages were opened or the juice prepared and

- 24 hours after.

The second measurement was required because juice was not always entirely consumed immediately after preparation. The $\mathrm{pH}$ values were obtained using a digital $\mathrm{pH}$ electrode (Whatman PHA 2000) that was calibrated immediately prior to use.

\section{Surface microhardness and roughness analysis}

The baseline surface microhardness ( $\mathrm{SMHb}$ ) of the enamel was measured using a Knoop indentor attached to a microhardness tester (Shimadzu Micro Hardness Tester HMV-2, Shimadzu Corporation, Kyoto, Japan). A line of five indentations was made on the enamel surface, $100 \mu \mathrm{m}$ from the acrylic resin margin. The indentation load was $50 \mathrm{~g}$ with $15 \mathrm{~s}$ dwell time. Only enamel specimens with a microhardness ranging from 300 to $370 \mathrm{KHN}$ were considered for the study.

The baseline surface roughness of the specimens 
Table 1 - Experimental groups.

\begin{tabular}{|c|c|c|c|}
\hline Group & Commercial name - manufacturer & Presentation & Composition \\
\hline 1 & Control & - & Distilled water \\
\hline 2 & Santal $^{\circledR}$ - Parmalat, Jundiai, Brazil & Concentrated grape juice (pack) & Citric acid, antioxidant, ascorbic acid, water, sugar \\
\hline 3 & Frug $^{\circledR}$ - Frugos Ltda., Olimpia, Brazil & Concentrated grape juice (pack) & Citric acid, antioxidant, arcorbic acid, water, sugar \\
\hline 4 & Camp $^{\otimes}$ - General Brands, Guarulhos, Brazil & Powdered grape juice & Citric acid, fumaric acid, sugar \\
\hline 5 & Tang $^{\circledR}$ - Kraft Foods, Curitiba, Brazil & Powdered grape juice & Citric acid, fumaric acid, sugar \\
\hline 6 & Maguary ${ }^{\circledR}$ - Kraft Foods, Araguari, Brazil & $\begin{array}{l}\text { Concentrated grape juice } \\
\text { (bottle) }\end{array}$ & $\begin{array}{l}\text { Concentrated grape juice, arcorbic acid, citric } \\
\text { acid, acidulant, water, sugar }\end{array}$ \\
\hline
\end{tabular}

was evaluated using a roughness tester (Surftest 301 - Mitutoyo, São Paulo, Brazil). Each specimen was submitted to a first roughness reading in 5 different areas $(0.25 \mathrm{~mm} / \mathrm{s})$, and average values $\left(R_{a}\right)$ were calculated.

\section{Erosive challenge}

After the baseline microhardness and roughness values were recorded, the specimens were immersed manually in $25 \mathrm{~mL}$ of grape juice or distilled water (Table 1) for 10 minutes at room temperature. A multipurpose pump (Better 500, Sarlo Better Equipamentos Ltda ${ }^{\circledR}$ - São Caetano do Sul, Brazil) at a velocity of $3600 \mathrm{rpm}$ was used to maintain agitation. The juices were prepared according to the manufacturer's instructions. This procedure was repeated 4 times a day at three-hour intervals for 15 days, and a new solution was prepared for each cycle. $^{12}$

Between erosive cycles and during the remaining time, the specimens were kept in artificial saliva $\left(1.5 \mathrm{mmolL}^{-1} \mathrm{Ca}\left[\mathrm{NO}_{3}\right]_{2} .4 \mathrm{H}_{2} \mathrm{O}, 0.9 \mathrm{mmolL}^{-1}\right.$ $\mathrm{NaH}_{2} \mathrm{PO}_{4} \cdot 2 \mathrm{H}_{2} \mathrm{O}, 150 \mathrm{mmolL}^{-1} \mathrm{KCl}, 0.1 \mathrm{molL}^{-1}$ Tris buffer, $0.03 \mathrm{ppm} \mathrm{F}, \mathrm{pH} 7.0,30 \mathrm{~mL}$ per tooth) at room temperature. ${ }^{13}$

Alterations in the enamel after the erosive challenge were evaluated according to hardness loss and surface wear on the $5^{\text {th }}, 10^{\text {th }}$ and $15^{\text {th }}$ days of the experiment. The subsequent microhardness tests $\left(\mathrm{SMH}_{\mathrm{f}}\right)$ were performed in different (random) areas of the blocks following the same protocol. This method has been shown to efficiently determine minimal changes in surface hardness and the erosive attack. ${ }^{5}$ The average was then determined and used to represent the specimen's hardness value.
The percentage of surface microhardness change in the enamel was calculated as follows:

$$
\% \mathrm{SMHC}=100 \times\left(\mathrm{SMH}_{\mathrm{b}}-\mathrm{SMH}_{\mathrm{f}}\right) / \mathrm{SMH}_{\mathrm{b}}
$$

where $\mathrm{b}=$ baseline and $\mathrm{f}=$ final.

Surface wear (roughness) was determined in relation to the initial evaluation. Five scans were performed on each specimen from the reference to the exposed surface, and an average $\left(\mathrm{R}_{\mathrm{a}}\right)$ was obtained for each group at the different time points after the erosive challenges. The same operator performed all measures.

\section{Statistical analysis}

The normal distribution of data and equality of variances were confirmed using Anderson-Darling and Levene tests, respectively. A two-way ANOVA for repeated measures and Tukey's post hoc test were used for statistical comparisons among groups and averages, respectively. The significance level was set at $5 \%$. Additionally, Pearson's correlation test was used to compare the roughness and microhardness values.

\section{Results}

The $\mathrm{pH}$ values for all of the beverages are shown in Table 2. The grape juices presented $\mathrm{pH}$ values between 2.9 and 3.5. The differences between the baseline $\mathrm{pH}$ and the $\mathrm{pH} 24$ hours later were not significant $(\mathrm{p}=0.1387)$.

All of the tested juices promoted significant loss of superficial enamel hardness on the fifth day of immersion compared to the initial period $(\mathrm{p}<0.05)$ 
and caused a significant increase in surface roughness $\left(\mathrm{R}_{\mathrm{a}}\right)$ by the tenth day in relation to the control group ( $<<0.05$ ).

At the $5^{\text {th }}$ day, it was possible to note that G4 presented a higher erosive potential than G6, G5 and G3 $(\mathrm{p}<0.05)$ because it presented higher surface microhardness loss. On the $10^{\text {th }}$ and $15^{\text {th }}$ days, the samples presented similar microhardness (Figure 1).

Regarding the roughness assessment, Groups G2, G3, G4 and G5 had similar roughness that was higher than that of the control group, but G6 was similar to all of them until the $10^{\text {th }}$ day. For each day of the experiment, the roughness results for all of the experimental groups were different from those of the control group (Figure 2).

\section{Discussion}

Diet is the most extensively studied etiologic factor in dental erosion. ${ }^{14,15}$ The low cost and availability of acidic fruit juices, fruit drinks and carbonated beverages encourage their consumption, which may
Figure 1 - Knoop surface microhardness after the erosive challenge.

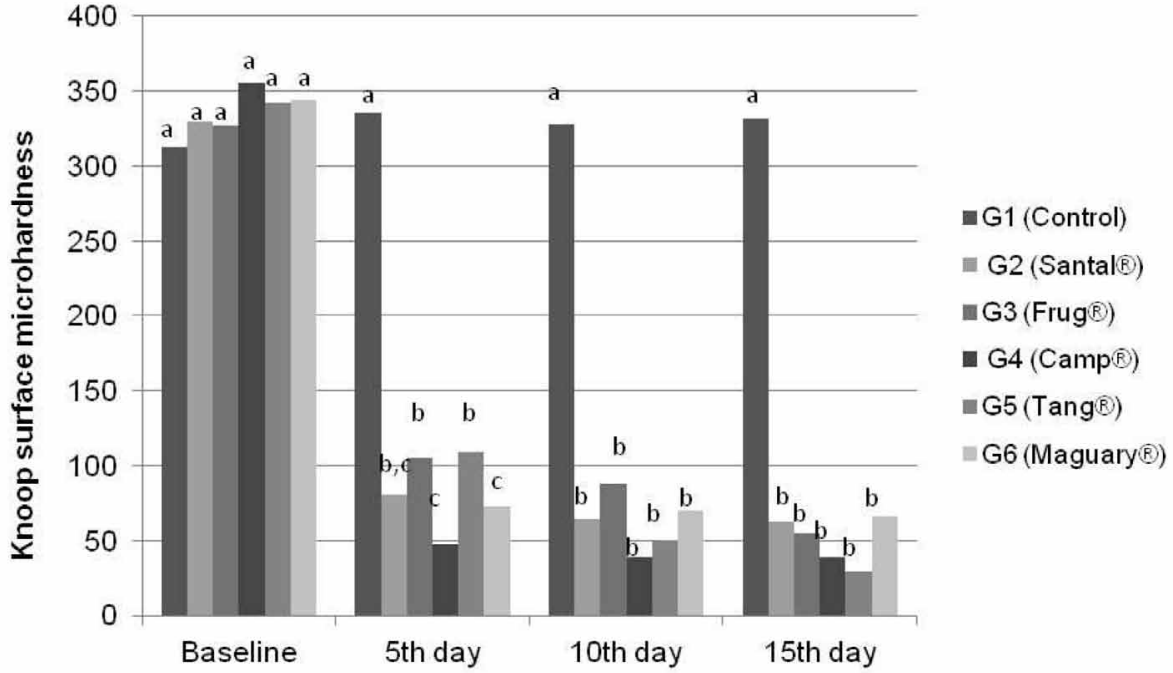

Different letters indicate statistically significant differences $(p<0.05)$

Figure 2 - Surface roughness following the erosive challenge $\left(R_{a}\right)$.

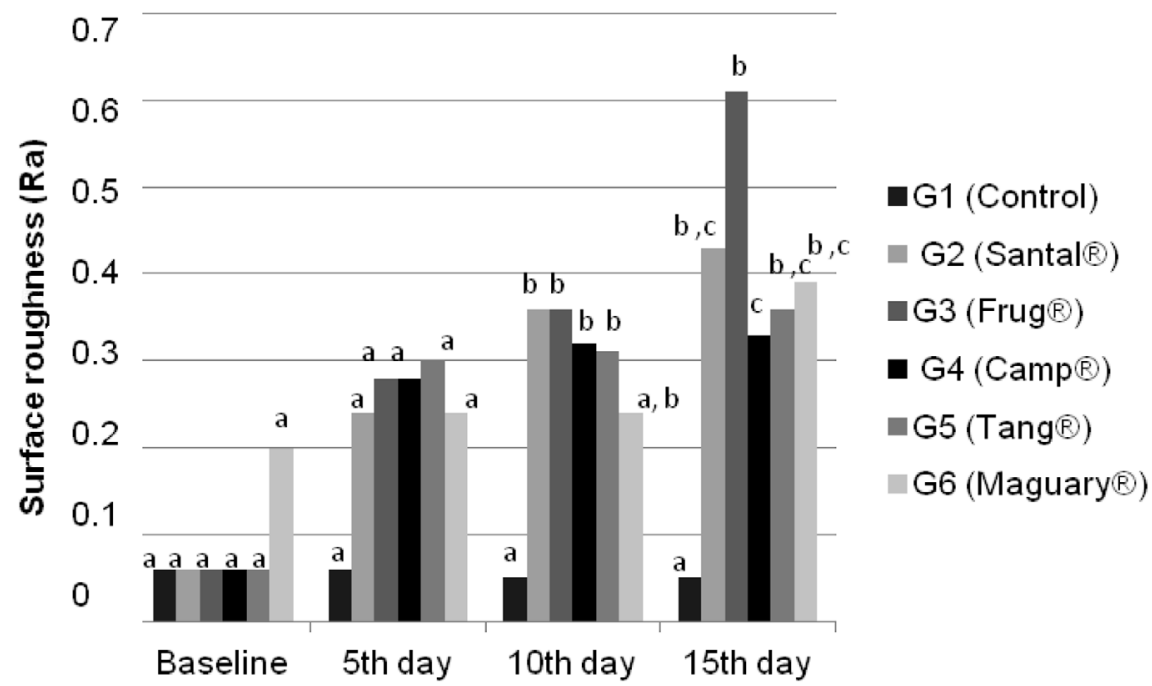

Different letters indicate statistically significant differences $(p<0.05)$ 
Table 2 - $\mathrm{pH}$ values of juices immediately (1) and 24 hours after the opening of the packages or preparation (2).

\begin{tabular}{l|c|c}
\hline \multicolumn{1}{c|}{ Beverage } & $\mathrm{pH}(1)$ & $\mathrm{pH}(2)$ \\
\hline Control - G1 & 5.1 & 5.1 \\
\hline Santal $^{\circledR}-\mathrm{G} 2$ & 3.2 & 3.0 \\
\hline Frug $^{\circledR}-\mathrm{G} 3$ & 2.9 & 2.7 \\
\hline $\mathrm{Camp}^{\circledR}-\mathrm{G} 4$ & 3.5 & 3.2 \\
\hline Tang $^{\circledR}-\mathrm{G} 5$ & 3.5 & 3.1 \\
\hline Maguary $^{\circledast}-\mathrm{G6}$ & 3.5 & 3.3 \\
\hline
\end{tabular}

lead to an elevated prevalence of dental erosion.

The present investigation aimed to evaluate the impact of grape juice on the enamel structure in terms of hardness and roughness because fruit juices are one the beverages that children most frequently consume. ${ }^{10}$ All of the studied juices caused significant mineral loss from the dental enamel over the time, a finding that was also observed in similar studies. ${ }^{16}$ For convenience, bovine enamel was used for this investigation; it has also been used for previous in vitro studies that investigated the erosion phenomenon. ${ }^{17}$ Although there is a direct correlation in changes of human and bovine enamel hardness, morphological differences, such as the higher porosity of bovine enamel, can result in the formation of more extensive erosive lesions. The erosion process seems to occur twice as quickly in bovine enamel than in permanent human enamel and 1.5 times faster than in deciduous human enamel. ${ }^{18} \mathrm{An}$ other limitation is that in vitro conditions do not exactly represent in vivo conditions. Clinical conditions imply the presence of tooth pellicle or the effects of salivary buffering, which may play a major role in moderating the extent of erosion in vivo. ${ }^{19}$

Larsen et al. ${ }^{20}$ investigated the erosive potential of soft drinks, mineral waters and orange juices and compared erosion depths to the beverages' $\mathrm{pH}$ and buffering capacity. The authors reported that erosion was minimal for beverages with a $\mathrm{pH}$ above 4.2 but became more evident at pHs below 4.0. In the present study, the $\mathrm{pH}$ values observed for the studied beverages ranged between 2.9 and 3.5, which is in accordance with previous studies regarding the erosive potential of beverages. ${ }^{8,15}$ However, one study confirmed the erosive potential of apple juice, which has $\mathrm{pH}$ values ranging from 3.3 to $4.2,{ }^{11}$ higher than the values found in our study. This finding may be related to the presence of tartaric acid, the main acid component of grapes. As can be noted in Table 1 and Figures 1 and 2, our study demonstrates that a lower $\mathrm{pH}$ value does not necessarily indicate a higher erosive potential. Because foodstuffs with a lower $\mathrm{pH}$ generally have a greater erosive effect, the mentioned fact can be explained because these values are both low and similar. According to Zero and Lussi, ${ }^{21}$ the erosive potential of an acidic drink is not completely dependent on its $\mathrm{pH}$; it is also determined by its buffering capacity and its calciumchelating properties. Factors such as temperature and concentration, as well as the frequency of consumption, may also influence a beverage's erosive potential $^{22}$ as well as the frequency of ingestion. ${ }^{23}$

When considering the erosive phenomenon in children, behaviour must also be considered. Unusual eating, drinking and swallowing habits such as holding an acidic beverage in the mouth before swallowing increase the substance's contact with dental structures. Bedtime consumption of acidic beverages is also considered as a risk factor, especially for children. Thus, education about dietary habits and lifestyle changes may be the best way to prevent dental erosion. When substantial loss of tooth structure occurs, restorative materials can be used to re-establish tooth function and aesthetics and to control hypersensitivity. However, it is important to realise that it is impossible to prevent the progression of erosion lesions unless etiologic factors are removed. Other preventive methods, such as the use of glass ionomer cement ${ }^{24}$ and topical fluoride, do not completely prevent erosion..$^{25}$

Our study also evaluated the erosive potential of different commercially available forms of the juices (powdered or concentrate); however, no significant difference was observed between groups. This can likely be explained by the similar compositions of the juices. The erosive activity of citric, malic, phosphoric and other acid ingredients in beverages and foodstuffs has been demonstrated in many in vitro, in situ and in vivo studies. ${ }^{1}$ Citric acid is a common buffer component in many artificial fruit juices. It 
may act as a chelator capable of binding the minerals (calcium) of enamel or dentine, thus increasing the degree of undersaturation and favouring demineralisation. ${ }^{26}$ One study investigated the effect of dilution on the erosive potential of dilutable fruit drinks. ${ }^{27}$ The authors found that only a great increase in the dilution factor (1:15) of some of the tested products produced a statistically significant reduction in in vitro enamel erosion. The addition of water to an acceptable consumption level (1:3) did not diminish the beverages' erosive potential. Dilutable fruit juices are generally considered safer, as the consumer can control their composition; however, dilution should not be viewed as an advantage of powdered juices.

The methods used in the present study may represent a limitation, considering the degree of the erosive lesions formed by the erosive challenge. According to Young and Tenuta, ${ }^{28}$ initial erosion starts with an early-stage surface softening, but prolonged

\section{References}

1. Lussi A, Hellwig E, Ganss C, Jaeggi T. Buonocore Memorial Lecture. Dental erosion. Oper Dent. 2009 MayJun;34(3):251-62.

2. Murakami C, Oliveira LB, Sheiham A, Nahas Pires Correa MS, Haddad AE, Bonecker M. Risk indicators for erosive tooth wear in brazilian preschool children. Caries Res. 2011 Mar 23;45(2):121-9.

3. van Rijkom HM, Truin GJ, Frencken JE, Konig KG, van 't Hof MA, Bronkhorst EM, et al. Prevalence, distribution and background variables of smooth-bordered tooth wear in teenagers in the hague, the Netherlands. Caries Res. 2002 MarApr;36(2):147-54.

4. Taji S, Seow WK. A literature review of dental erosion in children. Aust Dent J. 2010 Dec;55(4):358-67; quiz 475.

5. Lussi A, Kohler N, Zero D, Schaffner M, Megert B. A comparison of the erosive potential of different beverages in primary and permanent teeth using an in vitro model. Eur J Oral Sci. 2000 Apr;108(2):110-4.

6. Harding MA, Whelton H, O’Mullane DM, Cronin M. Dental erosion in 5-year-old Irish school children and associated factors: a pilot study. Community Dent Health. 2003 Sep;20(3):165-70.

7. Lussi A, Kohler N, Zero D, Schaffner M, Megert B. A comparison of the erosive potential of different beverages in primary and permanent teeth using an in vitro model. Eur J Oral Sci. 2000 Apr;108(2):110-4. exposure to acids may dissolve the outer enamel layer and promote permanent loss of structure. In this way, superficial microhardness may not be the best method of quantifying the amount of structure lost by the erosive process ${ }^{29}$ and may only quantify the remaining softened tissue. This may explain why similar microhardness values were found for all groups from the tenth day forward. Others studies have used such parameters to analyse beverage-related dental erosion, suggesting that the complexity of the erosive process requires more than one type of analysis. ${ }^{30}$

\section{Conclusions}

This in vitro study demonstrated that in general grape juices have considerable erosive potential: all of the studied juices were capable of causing significant loss of dental enamel. The form of the products (powdered or concentrated) had no influence on their erosive potential.

8. Grobler SR, Senekal PJ, Kotze TJ. The degree of enamel erosion by five different kinds of fruit. Clin Prev Dent. 1989 Sep-Oct;11(5):23-8.

9. Al-Majed I, Maguire A, Murray JJ. Risk factors for dental erosion in 5-6 year old and 12-14 year old boys in Saudi Arabia. Community Dent Oral Epidemiol. 2002 Feb;30(1):38-46.

10. Ng SW, Ni Mhurchu C, Jebb SA, Popkin BM. Patterns and trends of beverage consumption among children and adults in Great Britain, 1986-2009. Br J Nutr. 2011 Dec 20:1-16; [Epub ahead of print]. http://journals.cambridge.org/action/ displayAbstract ? fromPage $=$ online $\&$ aid $=8465923$.

11. Willershausen B, Callaway A, Azrak B, Duschner H. Influence of apple juice on human enamel surfaces of the first and second dentition - an in vitro study. Eur J Med Res. 2008 Jul $28 ; 13(7): 349-54$.

12. Meurman JH, Harkonen M, Naveri H, Koskinen J, Torkko $\mathrm{H}$, Rytomaa I, et al. Experimental sports drinks with minimal dental erosion effect. Scand J Dent Res. 1990 Apr;98(2):120-8.

13. Vieira AE, Delbem AC, Sassaki KT, Rodrigues E, Cury JA, Cunha RF. Fluoride dose response in $\mathrm{pH}$-cycling models using bovine enamel. Caries Res. 2005 Nov-Dec;39(6):514-20.

14. Wongkhantee S, Patanapiradej V, Maneenut C, Tantbirojn D. Effect of acidic food and drinks on surface hardness of enamel, dentine, and tooth-coloured filling materials. J Dent. 2006 Mar;34(3):214-20. 
15. Lussi A, Jaeggi T, Zero D. The role of diet in the aetiology of dental erosion. Caries Res. 2004;38 Suppl 1:34-44.

16. Seow WK, Thong KM. Erosive effects of common beverages on extracted premolar teeth. Aust Dent J. 2005 Sep;50(3):1738; quiz 211.

17. Hannig M, Balz M. Protective properties of salivary pellicles from two different intraoral sites on enamel erosion. Caries Res. 2001 Mar-Apr;35(2):142-8.

18. Amaechi BT, Higham SM, Edgar WM. Factors influencing the development of dental erosion in vitro: enamel type, temperature and exposure time. J Oral Rehabil. 1999 Aug;26(8):62430.

19. Brunton PA, Hussain A. The erosive effect of herbal tea on dental enamel. J Dent. 2001 Nov;29(8):517-20.

20. Larsen MJ, Richards A. Fluoride is unable to reduce dental erosion from soft drinks. Caries Res. 2002 Jan-Feb;36(1):75-80.

21. Zero DT, Lussi A. Erosion--chemical and biological factors of importance to the dental practitioner. Int Dent J. 2005;55(4 Suppl 1):285-90.

22. Lussi A, Schlueter N, Rakhmatullina E, Ganss C. Dental erosion - an overview with emphasis on chemical and histopathological aspects. Caries Res. 2011;45 (Suppl 1):2-12.

23. Johansson AK, Lingstrom P, Imfeld T, Birkhed D. Influence of drinking method on tooth-surface $\mathrm{pH}$ in relation to dental erosion. Eur J Oral Sci. 2004 Dec;112(6):484-9.
24. Salas CF, Guglielmi CA, Raggio DP, Mendes FM. Mineral loss on adjacent enamel glass ionomer cements restorations after cariogenic and erosive challenges. Arch Oral Biol. 2011 Oct;56(10):1014-9.

25. Murakami C, Bonecker M, Correa MS, Mendes FM, Rodrigues CR. Effect of fluoride varnish and gel on dental erosion in primary and permanent teeth. Arch Oral Biol. 2009 Nov;54(11):997-1001.

26. West NX, Hughes JA, Addy M. Erosion of dentine and enamel in vitro by dietary acids: the effect of temperature, acid character, concentration and exposure time. J Oral Rehabil. 2000 Oct;27(10):875-80.

27. Hunter ML, Patel R, Loyn T, Morgan MZ, Fairchild R, Rees JS. The effect of dilution on the in vitro erosive potential of a range of dilutable fruit drinks. Int J Paediatr Dent. 2008 Jul;18(4):251-5.

28. Young A, Tenuta LM. Initial erosion models. Caries Res 2011;45 Suppl 1:33-42.

29. Schlueter N, Hara A, Shellis RP, Ganss C. Methods for the measurement and characterization of erosion in enamel and dentine. Caries Res. 2011;45 Suppl 1:13-23.

30. Rios D, Honorio HM, Francisconi LF, Magalhaes AC, de Andrade Moreira Machado MA, Buzalaf MA. In situ effect of an erosive challenge on different restorative materials and on enamel adjacent to these materials. J Dent. 2008 Feb;36(2):152-7. 